Tomasz Biernat*

Toruń

\title{
Czy istnieje rodzina ponowoczesna?
}

Pytanie sformułowane w tytule może wydawać się naiwne albo prowokacyjne. O ile w literaturze przedmiotu można znaleźć opisy rodziny tradycyjnej i nowoczesnej (ew. współczesnej) ${ }^{1}$, o tyle określenie „rodzina ponowoczesna" może budzić kontrowersje. Celem niniejszego artykułu będzie próba zastanowienia się nad przemianami rodziny, które dokonały się w czasie ostatnich kilku dekad. Ich specyfika i głębokość sprawia, że niektórzy badacze rodziny wręcz stawiają tezę o narodzinach rodziny ponowoczesnej. W tle postawionego pytania znajduje się kwestia bardziej podstawowa i wzbudzająca wiele sporów - pytanie o ponowoczesność. Kłopot z ponowoczesnością wynika z tego, że nie wiemy, czy ona istnieje. W eseju pt. Cywilizacja na ławie oskarżonych Leszek Kołakowski w następujący sposób podsumował dyskusję na temat ponowoczesności: „Nie wiedząc, czym jest «nowoczesność», próbujemy ostatnio ucieczki do przodu od naszego pytania i mówimy o «postnowoczesności» [...]. Nie wiem czym jest «ponowoczesność», i czym się różni od «przed-nowoczesności», nie mam też wrażenia, że

* Dr hab. Tomasz Biernat, prof. UMK, jest kierownikiem Katedry Pracy Socjalnej w Wydziale Nauk Pedagogicznych Uniwersytetu Mikołaja Kopernika w Toruniu.

1 Takie ujęcie można znaleźć chociażby w klasycznej pracy Z. Tyszki pt. Socjologia rodziny (Warszawa: PWN 1979, s. 90-140) lub F. Adamskiego, Rodzina. Wymiar społeczno-kulturowy, Kraków:Wydawnictwo Uniwersytetu Jagiellońskiego 2002, s. 151-175. Przyjętą cezurą czasową oddzielającą rodzinę tradycyjną od nowoczesnej jest rewolucja przemysłowa (XVIII-XIX wiek), która zapoczątkowała proces modernizacji społeczeństwa (w Polsce modernizacja na skutek rozbiorów i zacofania miała inny charakter niż na zachodzie Europy i dokonała się później). 
powinienem wiedzieć. A cóż może przyjść po postnowoczesności?”2. Wśród badaczy społecznych można znaleźć zarówno zwolenników, jak i przeciwników tezy o istnieniu ponowoczesności jako nowej epoki w dziejach tak zwanego zachodniego społeczeństwa. Jednym ze wskaźników zachodzących przemian jest stosowanie w nazwach różnych zjawisk przedrostka ,post”, na przykład: posthistoria, postcywilizacja, postindustrialność (D. Bell ${ }^{3}$ ), postmaterializm (R. Ingelhardt ${ }^{4}$ ), postpolityka (F. Fukuyama ${ }^{5}$ ), posthumanizm (N. Badmington ${ }^{6}$, postkultura, postnauka. Ich użycie ma sugerować, że dokonała się jakaś generalna zmiana społeczna, że coś się definitywnie zakończyło i zapoczątkowało „nową” rzeczywistość różną jakościowo od poprzedniej’ Związek między rodziną a społeczeństwem jest znany od starożytności. Twórcy nowożytnej socjologii zwracali uwagę na jego fundamentalną rolę i znaczenie rodziny dla społeczeństwa (np. A. Comte, B. Malinowski, T. Parsons). Wydaje się jednak, że związek ten w ostatnich czasach znacznie osłabł, na co wskazują na przykład dane demograficzne i różne fakty społeczne, o których piszemy w dalszej części artykułu. Wielkie procesy, takie jak globalizacja, pluralizacja, indywidualizacja, rozwój nowoczesnych technologii telekomunikacyjnych i informatycznych, mają niewatpliwy wpływ na rodzinę i nie do końca zdajemy sobie sprawę, jak duży i znaczący on jest. Poniższy tekst jest refleksją nad przydatnością kategorii opisowej „rodzina ponowoczesna" dla rozumienia przemian współczesnej rodziny.

\section{Rodzina w ponowoczesności?}

Czy ponowoczesność jest nową rzeczywistością społeczno-kulturową, w której żyjemy, czy jedynie nową etykietą podlegającej intensyfikacji no-

${ }^{2}$ L. Kołakowski, Cywilizacja na ławie oskarżonych, Warszawa: ResPublica 1990, s. 201.

3 Por. D. Bell, Nadejście społeczeństwa postindustrialnego: próba prognozowania spotecznego, Warszawa: Instytut Badania Współczesnych Problemów Kapitalizmu 1975 (cz. 1-4).

${ }^{4}$ R. Inglehart, The Silent Revolution: Changing Values and Political Styles among Western Publics, Princeton: Princeton University Press 1977.

${ }^{5}$ F. Fukuyama, Koniec historii, Warszawa: Zysk i Ska 1996.

${ }^{6}$ N. Badmington, Posthumanism, Basingstoke-New York: Palgrave 2000.

${ }^{7} \mathrm{~K}$. Stachewicz, O (nad)używaniu przedrostka ,post” w czasach (po)nowoczesnych, „Teologia i Moralność” 11 (2012), s. 131. 
woczesności określanej jako późna ${ }^{8}$, płynna ${ }^{9}$, druga ${ }^{10}$ ? Wielu obserwatorów życia, zarówno badaczy, jak i tak zwanych zwykłych ludzi, dostrzega pewną zasadniczą zmianę - używając języka fenomenologów - ,świata, w którym żyjemy". Przeobrażenia, jakie dokonały się w drugiej połowie XX i na początku XXI wieku, objęły właściwe każdy aspekt ludzkiego życia. Już prawie czterdzieści lat temu Daniel Bell w książce pt. The Cultural Contradictions of Capitalism pisał o dokonującej się postmodernistycznej rewolucji, która według niego polega na rozbieżności między kulturą i strukturą społeczną (stawiał nawet tezę o „napaści” kultury na strukturę społeczna). Pisał on wówczas: „Nowa rewolucja już się rozpoczęła i to w dwojakim sensie. Po pierwsze, autonomia kultury osiagnięta w sztuce zaczęła przenikać do życia codziennego. Postmodernistyczna postawa domaga się, by to, co uprzednio rozgrywało się tylko w fantazji i wyobraźni, zaczęło naprawdę dziać się w życiu. Różnica między sztuką a życiem znikła. Wszystko, co dozwolone w sztuce, staje się dozwolone również w życiu"11. Po drugie, styl ten, do tej pory charakteryzujący wąskie, elitarne grupy społeczeństwa, zaczął obejmować coraz szersze jego kręgi i znacząco oddziaływać na większość. Rewolucyjne zmiany zapoczątkowane prawie pół wieku temu obecnie obejmują szerokie spektrum funkcjonowania jednostki i społeczeństwa. Współczesny badacz Aharon Aviram uważa, że w naszych czasach równolegle dokonuje się kilkanaście rewolucji, mających głęboki wpływ na kształt ludzkiego życia w prawie każdym jego wymiarze ${ }^{12}$. Przemiany dotykają kwestii fundamentalnych dla istnienia społeczeństwa, takich jak: wartości, normy społeczne, role, obyczaje, styl życia, sposoby i zasady zbiorowego funkcjonowania. Zachodzą one również w sferze definicji płci i ról społecznych, charakteru związków międzyludzkich, w tym również małżeństwa i rodziny. Mają one związek z szerszymi zmianami mentalnościowymi i światopoglądowymi wynikającymi z upadku tak zwanych wielkich metanarracji (F. Lyotard), służących człowiekowi do opisu i rozumienia świata (nauka, religia). Kwestionowanie i relatywizowanie wartości do niedawna

${ }^{8}$ A. Giddens, Nowoczesność i tożsamość. „Ja” i społeczeństwo w epoce późnej nowoczesności, Warszawa: PWN 2001.

9 Z. Bauman, Płynna nowoczesność, Kraków: Wydawnictwo Literackie 2006.

${ }^{10}$ U. Beck, Władza i przeciwwładza w epoce globalnej. Nowa ekonomia polityki światowej, Warszawa: Wydawnictwo Naukowe Scholar 2005.

${ }_{11}$ D. Bell, Kulturowe sprzeczności kapitalizmu, Warszawa: PWN 1998, s. 89 (praca w oryginale została po raz pierwszy opublikowana w 1976 roku).

12 A. Aviram, Navigating Through the Storm. Reinventing Education for Postmodern Democracies, Rotterdam: Sense Publishers 2010. 
niekwestionowanych (małżeństwo, rodzina, dziecko, wierność, czystość) stało się obecnie powszechną i aprobowaną praktyką społeczną. Przemiany świadomości społecznej mają oczywiście konsekwencje w ludzkich zachowaniach i wyborach.

Więzi między rodziną a społeczeństwem są niekwestionowane. Rodzina jest swoistą emanacją społeczeństwa, nie tylko istnieje w społeczeństwie, ale społeczeństwo na swój sposób jest obecne w niej. Już po II wojnie światowej zaobserwowano ważne i szybkie zmiany w funkcjonowaniu rodziny. W głośnej pracy na temat rodziny opublikowanej na początku lat pięćdziesiątych E. W. Burgess i H. J. Locke postawili tezę, że rodzina przekształca się z instytucji w rodzaj związku towarzyskiego opartego na innych niż do tej pory zasadach $^{13}$. Według Christiny Hardyment, od lat 50. XX wieku rodzina zaczęła się istotnie zmieniać w wielu wymiarach. Dokonuje się to na skutek szybkiej poprawy warunków materialnych życia, ewolucji roli kobiety, przemian w wykorzystaniu czasu wolnego oraz zmiany postaw. Według autorki, ich podłożem były ,zmiany w myśleniu o tym, jak powinniśmy się zachowywać, przechodzenie od sztywnej społecznej poprawności do otwartości umysłu oraz od nacisku kładzionego na jednolitość obyczajów do szacunku dla prywatności jednostki" ${ }^{14}$. Dotyczy to także pojmowania rodziny, jej celów, form, sposobu tworzenia, warunków trwania i rozpadu.

Analiza przemian współczesnej rodziny w tak zwanym świecie zachodnim coraz częściej budzi uzasadniony niepokój o jej kondycję i rozwój. Nawet ostatni nadzwyczajny synod biskupów zwołany przez papieża Franciszka dla omówienia sytuacji rodziny otwarcie uznaje istnienie kryzysu tej instytucji. Przedstawiona na synodzie diagnoza zawiera całą listę jego wskaźników: spadek urodzeń (brak zastępowalności pokoleń), związki nieformalne, małżeństwa etapowe, współżycie przed ślubem, dzieci pozamałżeńskie, aborcja, rozwody, przemoc, wykorzystywanie seksualne kobiet i dzieci, indywidualizm i relatywizm, nieobecność ojców, samotność, porzucanie osób starszych, zaniedbywanie dzieci (dzieci ulicy), zarobkowe migracje niszczące rodziny ${ }^{15}$. To tylko niektóre wskaźniki kryzysu rodziny, który Papież określił jako „poważny”. Coraz liczniejsza grupa badaczy i obser-

13 E.W. Burgess, H. J. Locke, The Family: From Institution to Companionship, New York: American Book Co 1953.

${ }^{14}$ Ch. Hardyment, Rodzina, Warszawa: Prószyński i Ska 1999, s. 13-28.

15 Pełną ich listę zawiera Relatio z Nadzwyczajnego Zgromadzenia Ogólnego Synodu Biskupów. Patrz Internet: http://tygodnik.onet.pl/wwwylacznie/przedstawiamy-polskie-tlumaczenie-relatio-nadzwyczajnego-synodu-o-rodzinie/ncqft 
watorów społecznych skłania się do uznania bezprecedensowości przemian rodziny, głębokości i zakresu zachodzących zjawisk gruntowanie zmieniających kształt i funkcjonowanie tej instytucji. Jednym ze wskaźników dokonujących się przemian rodziny jest zmiana sposobu jej postrzegania w nauce, polityce i prawie ${ }^{16}$. Definicję rodziny w oficjalnych dokumentach UE zastąpiło szerokie i wieloznaczne określenie ,życie rodzinne" ${ }^{17}$. Widać w tych nowych definicjach odchodzenie od definicji esencjalistycznych tworzonych na podstawie prawa naturalnego i definicji normatywnych wywodzących się z nauki (socjologia, antropologia) i przechodzenie do definicji konstruktywistycznych, inkluzywnych. Włączają one w swój szeroki zakres różne formy życia rodzinnego, w których występuje jakaś forma „rodzinności”. Niektórzy badacze wręcz stwierdzają, że obecnie ze względu na wiele postaci rodziny nie ma możliwości sformułowania jednej uniwersalnej definicji rodziny (tyle definicji, ile rodzin). W związku z tym raczej powinno się mówić o rodzinach niż rodzinie lub post-rodzinnych rodzinach, które są efektem ,pluralizacji życia rodzinnego" i powstawania jego alternatywnych form ${ }^{18}$. Zmiany obserwuje się również w potocznych definicjach. Młode pokolenie w różnych krajach rozszerza definicję rodziny i obejmuje nią partnerów dowolnej płci, bez ślubu i bez dzieci ${ }^{19}$. Rozszerzanie definicji rodziny nie jest tylko zabiegiem formalnym - jest odzwierciedleniem dokonujących się przemian społecznych związanych z rodzina.

\section{Ponowoczesność w rodzinie?}

Przedrostek ,post” zaczęto stosować również w odniesieniu do rodziny na określenie przemian, jakie w niej się dokonały ${ }^{20}$. W literaturze zachodniej termin rodzina postmodernistyczna pojawił się i upowszechnił się w latach 80. i 90. Podobno jako pierwszy użył go Edward Shorter w książce Making

${ }^{16}$ Por. T. Biernat, O przemianach definicji rodziny i ich konsekwencjach, „Społeczeństwo i Rodzina" 18 (2009), s. 28-40.

17 Tamże, s. 33.

${ }^{18} \mathrm{~K}$. Slany, Alternatywne formy życia malżeńsko-rodzinnego w ponowoczesnym świecie, Kraków: Nomos 2008, s. 244.

19 Por. T. Biernat, Małżeństwo i rodzina w opiniach młodych Polaków, Niemców i Hiszpanów, „Kultura i Edukacja” 2 (2009), s. 72-73.

${ }^{20} \mathrm{~W}$ literaturze przedmiotu można znaleźć inne próby typologizowania rodziny w kontekście przemian społecznych, np. rodzina preindustrialna, industrialna i postindustrialna.Por. Z. Tyszka, Rodzina we współczesnym świecie, Poznań: Wydawnictwo Naukowe UAM 2001. 
of the Modern Family w 1975 roku $^{21}$. Wyłanianie się rodziny ponowoczesnej uzasadnił nasypującymi zmianami, różniącymi ją od rodziny nowoczesnej (modernistycznej):

- indyferencja dorastającego pokolenia wobec tożsamości rodziny,

- nietrwałość par małżeńskich,

- szybki wzrost wskaźnika rozwodów,

- destrukcja wyobrażenia ,gniazda rodzinnego” spowodowana emancypacją kobiet (praca zawodowa),

- zmiany w socjalizacji dzieci,

- wpływ mediów legitymizujących różnicowanie się rodzin (uniformizacja standardów, wartości, stylów życia klasy średniej).

Podobny opis przemian rodziny,będących wskaźnikiem wyłaniania się jej nowej ponowoczesnej postaci, zawarł w swojej pracy pt. The Post-modern Family David Elkind w 1992 roku $^{22}$. Według Elkinda przekształcenie się rodziny modernistycznej (nazwanej przez T. Parsonsa nuklearna) w ponowoczesną wiąże się z następującymi zjawiskami:

- brak podstawowego bezpieczeństwa ekonomicznego rodziców,

- stres wynikający z relacji między pracą i rodzina,

- brak społecznego i instytucjonalnego wsparcia dla rodzin,

- wzmożone naciski na edukację (zarówno w stosunku do dzieci, jak i rodziców),

- rewolucja informatyczna (komputery, Internet, telekomunikacja).

Wskazane zjawiska mają charakter makrospołeczny. Dotykają wszystkich rodzin we współczesnym globalizującym się świecie oraz wywołują specyficzne zmiany w jej funkcjonowaniu.Wszyscy żyjemy w społeczeństwie ryzyka (U. Beck). Globalna utrata bezpieczeństwa, niestabilność, niepewność są znakiem naszych czasów. Rodziny żyją dziś pod nieustanną presją wielu zewnętrznych czynników i o wiele trudniej jest im uzyskać równowagę. Określenie „rodzina ponowoczesna” często stosowane jest na określenie nowych alternatywnych form życia małżeńsko-rodzinnego, takich jak: związki homoseksualne, kohabitacyjne, dobrowolnie bezdzietne, otwarte, małżeńskie seriale. Elkind, charakteryzując rodziny ponowoczesne, wcale nie wskazuje na tak zwane alternatywne formy życia małżeńsko-rodzinnego (tzw. niby rodziny, quasi-rodziny). Do rodzin ponowoczesnych zaliczył on: rodziny pracujących rodziców, rodziny rozbite, monoparentalne, adopcyjne i zrekonstruowane. Mówiąc o rodzinie ponowoczesnej, ma na myśli każdą

21 E. Shorter, Making of the Modern Family, New York: Basic Books 1975.

${ }^{22}$ Por. D. Elkind, The Post-modern Family. A New Imbalance, New York: Knopf 1992. 
rodzinę, która zanurzona jest z ponowoczesnej rzeczywistości. Interesujące porównanie rodziny $\mathrm{w}$ perspektywie międzykulturowej proponują Marian F. Zeitlin, Ratna Megawangi, Ellen M. Kramer, Nancy D. Colletta, E. D. Babatunde i David Garman w pracy Strengthening the Family - Implications for International Development. Zwrócili oni uwagę na fakt, że rodziny przednowoczesne i ponowoczesne są do siebie podobne i że różnią się od nowoczesnych ${ }^{23}$. Różnice między tymi „modelami” rodzin zaprezentowano w tabeli 1.

Tabela 1. Różnice między rodzinami nowoczesnymi oraz przed- i ponowoczesnymi ${ }^{24}$

\begin{tabular}{|l|l|}
\hline \multicolumn{1}{|c|}{$\begin{array}{c}\text { Rodziny nowoczesne } \\
\text { (r. modernistyczne) }\end{array}$} & \multicolumn{1}{|c|}{$\begin{array}{c}\text { Rodziny przed- i ponowoczesne } \\
\text { (r. pre- i postmodernistyczne) }\end{array}$} \\
\hline $\begin{array}{l}\text { Ostre rozróżnienie między domem } \\
\text { i miejscem pracy }\end{array}$ & Miejsce pracy i dom są często te same \\
\hline Miłość romantyczna & Miłość kontraktowa / konsensualna \\
\hline $\begin{array}{l}\text { Idealizacja matki jako legitymizowanej } \\
\text { opiekunki }\end{array}$ & $\begin{array}{l}\text { Współdzielone rodzicielstwo, pracujące } \\
\text { matki }\end{array}$ \\
\hline $\begin{array}{l}\text { Rodzina infantocentryczna } \\
\text { skoncentrowana na potrzebach dziecka }\end{array}$ & $\begin{array}{l}\text { Rodzina parentocentryczna } \\
\text { skoncentrowana na stylu życia } \\
\text { i życiowych celach dziecka oraz } \\
\text { społecznych gratyfikacjach }\end{array}$ \\
\hline Ochraniane, późne dojrzewanie dziecka & $\begin{array}{l}\text { Wczesne społeczne dojrzewanie } \\
\text { w pełnym zakresie dorosłej aktywności }\end{array}$ \\
\hline $\begin{array}{l}\text { Tożsamość jednostki definiowana } \\
\text { przez osobową narrację i osąd wartości }\end{array}$ & $\begin{array}{l}\text { Tożsamość płynnie określona } \\
\text { przez społeczny kontekst }\end{array}$ \\
\hline $\begin{array}{l}\text { Burzliwa adolescencja w celu } \\
\text { ustanowienia autonomii i oddzielenia } \\
\text { od rodziców }\end{array}$ & $\begin{array}{l}\text { Bardziej pokojowa adolescencja } \\
\text { z mniejszą potrzebą oddzielnego } \\
\text { mieszkania }\end{array}$ \\
\hline
\end{tabular}

${ }^{23} \mathrm{~W}$ niniejszym tekście stosowane są polskie odpowiedniki określeń pochodzących z języka angielskiego, choć niekiedy także w rodzimej literaturze można spotkać określenia: rodzina premodernistyczna - przednowoczesna, modernistyczna - nowoczesna, postmodernistyczna - ponowoczesna.

${ }^{24}$ M. F. Zeitlin, R. Megawangi, E. M. Kramer, N. D. Colletta, E. D. Babatunde, D. Garman, Strengthening the Family - Implications for International Development, Tokyo-New York-Paris: United Nations University Press 1995; źródło: http://archive.unu.edu/unupress/ unupbooks/uu13se/uu13se00.htm\#Contents (dostęp: 25.05.2014) 
Porównajmy rodzinę ponowoczesną z nowoczesną. Rodzina ponowoczesna różni się od rodziny nowoczesnej następującymi cechami. Miejscem pracy staje się często dom, a w rodzinie nowoczesnej istniała wyraźna granica między domem i pracą (były to oddzielne światy). Jest to związane $\mathrm{z}$ faktem, że wielu rodziców pracuje także w domu, gdzie nagminnie przynosi swoją pracę lub pracuje na odległość poprzez Internet. Miłość łącząca ludzi w związkach jest obecnie rodzajem kontraktu (miłość konsensualna) - romantyczny model miłości należy raczej do przeszłości. Wspólne dzielenie rodzicielstwa między rodziców w sytuacji pracującej matki w rodzinach ponowoczesnych stało się norma, w rodzinie nowoczesnej występowała idealizacja matki jako jedynej legitymizowanej opiekunki dla dziecka. Rodzinę ponowoczesną charakteryzuje wczesna socjalizacja i wprowadzanie dziecka w szerokie spektrum aktywności dorosłych (tzw. adultyzacja dzieciństwa). W rodzinie nowoczesnej dzieciństwo podlegało ochronie, a dorastanie było opóźniane. Zmienia się także pozycja rodziców i dziecka. Rodzina ponowoczesna skoncentrowana jest bardziej na rodzicach, tak zwana rodzina parentocentryczna i na ich potrzebach związanych z praca, podnoszeniem kwalifikacji, edukacją. Natomiast rodzina nowoczesna miała charakter infantocentryczny i była zorientowana na zaspokajanie potrzeb dziecka.W rodzinie ponowoczesnej tożsamość jest płynnie definiowana przez kontekst społeczny, inaczej niż w rodzinie nowoczesnej, gdzie indywidualna tożsamość definiowana była przez osobową narrację i osąd wartości. W rodzinach ponowoczesnych zanika tak zwany konflikt pokoleń między rodzicami i dziećmi, czego objawem jest na przykład bardziej pokojowa adolescencja z mniejszą potrzebą separacji. Rodzinę nowoczesną cechowała burzliwa adolescencja, która służyła ustanowieniu autonomii dorastających dzieci i oddzieleniu od rodziny.

Zasadnicza różnica między rodziną przed- i ponowoczesną a rodziną nowoczesną dotyczy relacji rodziny ze światem zewnętrznym ${ }^{25}$. Rodzinę modernistyczną oddzielały od świata wyraźne i czytelne granice zapewniające członkom rodziny bezpieczeństwo oraz chroniące ją przed niekorzystnymi wpływami otoczenia. Rodzina była rodzajem enklawy redukującej stres, dającej odpoczynek i wytchnienie (praca i rodzina były odrębnymi światami). Rodzina ponowoczesna $\mathrm{w}$ istocie jest podobna do rodziny przednowocze-

${ }^{25}$ Patrz: T. Biernat, Transformacja czy kryzys rodziny, w: W. Muszyński, E. Sikora (red.), Miłość, wierność i uczciwość na rozstajach współczesności. Kształty rodziny współczesnej, Toruń: Wydawnictwo Adam Marszałek 2008, s. 284-285. 
snej (tradycyjnej), w sferze kontaktów ze światem zewnętrznym ma on inny niż dawniej charakter. W rodzinie tradycyjnej więzi z otoczeniem społecznym były bezpośrednie i zachodziły w realnej rzeczywistości. Dzisiaj świat zewnętrzny przenika do rodziny za pośrednictwem nowoczesnych mediów i przekształca jej środowisko kulturowe. Kontakty ze światem zewnętrznym są w dużej mierze zapośredniczone. Przenikające do rodziny idee, światopoglądy, wartości, normy, style życia zmieniają jej funkcjonowanie. Osłabieniu ulega funkcja socjalizacyjno-wychowawcza i ideologiczna (światopoglądotwórcza) rodziny. Starsze pokolenie i jego przekaz światopoglądowy nie jest w stanie konkurować z wyrafinowanymi przekazami docierającymi z mediów. Styl życia młodego pokolenia istotnie się różni od stylu pokolenia rodziców. Młodzi ludzie często w otwarty sposób kontestują, a nawet odrzucają wzory życia dorosłych (religia, małżeństwo, tradycyjne wartości, normy obyczajowe). Proces ten różni się siłą i radykalizmem od tego, co było wcześniej $\mathrm{i}$ - co ciekawe - dzieje się często z aprobatą starszego pokolenia. Świat przenikający do rodziny poprzez elektroniczne media w subtelny sposób „rozpuszcza” środowisko społeczno-kulturowe rodziny, nasycając je wysoko perswazyjnymi oddziaływaniami. Rodzina ponowoczesna jednak nie jest rodzajem regresu do rodziny prenowoczesnej. Taka sytuacja nie jest możliwa. Między jednym i drugim typem występują różnice, które przedstawia tabela 2.

Tabela 2. Różnice pomiędzy rodzinami prenowoczesnymi i ponowoczesnymi ${ }^{26}$

\begin{tabular}{|l|l|}
\hline \multicolumn{1}{|c|}{$\begin{array}{c}\text { Rodziny przednowoczesne } \\
\text { (r. premodernistyczne) }\end{array}$} & \multicolumn{1}{|c|}{$\begin{array}{c}\text { Rodziny ponowoczesne } \\
\text { (r. postmodernistyczne) }\end{array}$} \\
\hline $\begin{array}{l}\text { Większe i bardziej zależne od więzi } \\
\text { rodowych }\end{array}$ & $\begin{array}{l}\text { Mniejsze i mniej zależne od więzi } \\
\text { rodowych }\end{array}$ \\
\hline $\begin{array}{l}\text { Większość życia ustanowiona na } \\
\text { bezpośredniej fizycznej płaszczyźnie }\end{array}$ & $\begin{array}{l}\text { Większość życia ustanowiona na } \\
\text { elektronicznie lub symbolicznie } \\
\text { usuwalnej płaszczyźnie }\end{array}$ \\
\hline Ilustracja: praca fizyczna & Ilustracja: praca umysłowa \\
\hline Bezpośrednie kontakty społeczne & $\begin{array}{l}\text { Elektroniczne zapośredniczone } \\
\text { lub symboliczne kontakty }\end{array}$ \\
\hline Konflikty fizyczne & Konflikty symboliczne \\
\hline
\end{tabular}

${ }^{26}$ Tamże. 
Tabela 2. Różnice pomiędzy rodzinami prenowoczesnymi (cd.)

\begin{tabular}{|c|c|}
\hline $\begin{array}{l}\text { Rodziny przednowoczesne } \\
\text { (r. premodernistyczne) }\end{array}$ & $\begin{array}{l}\text { Rodziny ponowoczesne } \\
\text { (r. postmodernistyczne) }\end{array}$ \\
\hline $\begin{array}{l}\text { Mała liczba stałych fizycznych } \\
\text { i społecznych kontekstów }\end{array}$ & $\begin{array}{l}\text { Bardzo duża liczba zmieniających się } \\
\text { fizycznych, symbolicznych } \\
\text { i społecznych kontekstów }\end{array}$ \\
\hline $\begin{array}{l}\text { Niskie zapotrzebowanie na umiejętności } \\
\text { gromadzenia i przetwarzania informacji }\end{array}$ & $\begin{array}{l}\text { Bardzo wysokie zapotrzebowanie } \\
\text { na gromadzenie i przetwarzanie } \\
\text { abstrakcyjnych informacji }\end{array}$ \\
\hline $\begin{array}{l}\text { Przymusowe uczestnictwo we } \\
\text { wszystkich aspektach wspólnego życia, } \\
\text { brak prywatności i osobistego wyboru }\end{array}$ & $\begin{array}{l}\text { Dowolne uczestnictwo w większości } \\
\text { aspektów wspólnego życia, wysoki } \\
\text { poziom prywatności i osobistego } \\
\text { wyboru }\end{array}$ \\
\hline $\begin{array}{l}\text { Tożsamość ograniczona do małej liczby } \\
\text { narzucanych ról społecznych }\end{array}$ & $\begin{array}{l}\text { Tożsamość zmienia się wraz } \\
\text { z wieloma zmienianymi, narzucanymi } \\
\text { i dowolnymi rolami }\end{array}$ \\
\hline $\begin{array}{l}\text { Władza tworzy i ustanawia zasady } \\
\text { warunkujące, co jest dobre i złe; } \\
\text { dosłowna, fundamentalna wiara } \\
\text { religijna }\end{array}$ & $\begin{array}{l}\text { Pluralistyczne, relatywne wartości, } \\
\text { nie-literalne, symboliczne interpretacje } \\
\text { większości twierdzeń wiary }\end{array}$ \\
\hline
\end{tabular}

Różnice między rodziną przednowoczesną i ponowoczesną wynikają ze zmienionego radykalnie kontekstu społecznego, w którym dziś funkcjonuje rodzina. Rewolucja telekomunikacyjna i informatyczna doprowadziła do usieciowienia i globalizacji rodziny. Rodzina stała się medium, przez które przepływają niewyobrażalne ilości informacji, można powiedzieć, że ulega ona swoistej medializacji. Nie jest już w stanie weryfikować, selekcjonować i kontrolować informacji, które do niej docierają i ją przekształcają. Do rodziny docierają również ponowoczesne dyskursy dekonstruujące myślenie o rzeczywistości. Objaśnianie świata nie jest już domeną rodziców czy starszych pokoleń. Młode pokolenie zdobywa własną wiedzę o świecie za pośrednictwem Internetu i telewizji. Rodzina w coraz mniejszym stopniu służy reprodukcji tak zwanej „twardej kultury” i wartości. Raczej staje się miejscem wytwarzania wysoce zindywidualizowanych „miękkich kultur", prywatnych moralności i pluralistycznych stylów życia (P. L. Berger). W rodzinach ponowoczesnych dzieci i dorośli tracą swoje zdefiniowane strukturą pokrewieństwa miejsce. Niektórzy badacze zwracają uwagę na towarzyszące przemianom rodziny przemiany dzieciństwa (zanikanie 
dzieciństwa - N. Postman, adultyzacja dzieciństwa, cyfrowe dzieciństwo D. Elkind).

\section{Konkluzja}

Czy istnieje rodzina ponowoczesna? Odpowiedź twierdząca oznaczałaby uznanie, że nastąpiła jakaś radykalna przemiana rodziny, która w istotny sposób ją przekształciła. Określenie „rodzina ponowoczesna” oznaczałaby, że poprzednia jej formuła „się" skończyła i że mamy do czynienia z zupełnie nową jej postacią. Czy tak jest? A co będzie po niej? Rodzina post-postmodernistyczna, neo postmodernistyczna, neo-antypostmodernistyczna? Większość badaczy rodziny jest zgodnych, że nadal dominująca będzie rodzina składająca się z rodziców obojga płci i dzieci. Choć przemiany rodziny są niezwykle złożone i trudne do uchwycenia, to należy uznać, że ich dynamika i głębokość może świadczyć, o czymś ważnym. To, co dokonało się z rodziną w tak krótkim czasie, świadczy o głębokich przemianach, które dotykają samej instytucji rodziny i jej funkcji. Możemy uznać, że dzisiejsza rodzina zawiera zarówno elementy rodzin nowoczesnych, ponowoczesnych, jak i pochodzących z rodzin tradycyjnych (nietrudno takie elementy wskazać). Przemieszanie cech rodzin wywodzących się z różnych ,,modeli” rodziny jest właśnie cechą charakterystyczną dzisiejszej rodziny. I już to jest zjawiskiem zasługującym na uwagę, ponieważ pociaga za sobą poważne konsekwencje dla samej rodziny, jak i całego społeczeństwa. Zrozumienie, jak funkcjonuje współczesna rodzina,wymaga uwzględnienia sposobu złożenia w niej tych elementów, proporcji między nimi oraz konsekwencji. Uwarunkowania społeczno-kulturowe rodziny nie zawsze są doceniane. Koncentracja na analizie rodziny z perspektywy psychologicznej nie zawsze jest wystarczająca. Problemy w realizacji funkcji rodziny, trudności w relacjach między małżonkami, problemy wychowawcze z dziećmi mogą mieć swoje przyczyny właśnie w uwarunkowaniach społeczno-kulturowych rodziny i wynikać ze zderzania elementów pochodzących z różnych modeli rodziny.

Dzieje ludzkości pokazały, że rodzina posiada bardzo dużą zdolność adaptacyjną i potrafi optymalnie dostosowywać się do zmieniających się warunków otoczenia. Wszystko wskazuje na to, że rodzina złożona z heteroseksualnych rodziców i dzieci będzie stanowić większość w społeczeństwie, jednak jej sposób działania i realizacji swoich celów może być odmienny i różnić się od tego, co było choćby jedno pokolenie wstecz. Według Davida Elkinda przyszła rodzina, którą nazywa rodziną żywotną (vital family) 
będzie mieszaniną najlepszych cech rodzin modernistycznych i postmodernistycznych ${ }^{27}$. Warunkiem jej prawidłowego funkcjonowania musi być odrzucenie słabych stron jednej i drugiej jej postaci. Perspektywa rodziny ponowoczesnej pomaga lepiej ją zrozumieć. Chociaż dyskusyjna, a nawet kontrowersyjna, rzuca ciekawe światło na przemiany współczesnej rodziny oraz prowokuje do empirycznej weryfikacji stawianych hipotez.

\section{Does a Postmodern Family Exist? (Summary)}

The main aim of the article was an attempt of a discussion on the changes of a contemporary family in the context of theses of the appearance of postmodern family. No one doubts that we live in a time of a deep and dynamic social changes which have drastically modified the picture of our families. The thesis of a postmodern society puts a question of the condition of a family, the society's natural emanation. The idea of "postmodern family" appeared at the end of the second half of the twentieth century and, in spite of its ambiguity, it is more and more often used to describe today's family. The article shows the main reasons of transformations, relations between social changes and family changes and describes some models of family: traditional (pre-modern), modern and postmodern. The author focuses on socio-cultural factors of the postmodern family. Observation of transformations that have been occurring, allows us to discover some new and specific features of a contemporary family. It may be important for understanding a family, scientific studies and various activities connected to its improvement. It is difficult to answer the question concerning the fact of the existence of a new, the so-called postmodern family. Maybe we need more time, distance and empirical data to notice this fact. The positive answer might determine serious consequences to family policy, education, family therapy and social work with families.

Keywords: traditional family, modern family, postmodern family, social changes, family changes in society

\section{Czy istnieje rodzina ponowoczesna? (Streszczenie)}

Głównym celem artykułu była próba dyskusji na temat przemian współczesnej rodziny w kontekście tez o pojawieniu się rodziny ponowoczesnej. Nikt nie ma wąt-

27 D. Elkind, Ties That Stress: The New Family Imbalance, Cambridge: Harvard University Press 1994, s. 209. 
pliwości, że żyjemy w czasach głębokich i dynamicznych przemian społecznych, które radykalnie zmieniły oblicze naszych rodzin. Często wysuwana obecnie teza o społeczeństwie ponowoczesnym stawia pytanie o stan i kondycję rodziny, która jest jego naturalną emanacją. Pojęcie „rodzina ponowoczesna” pojawiło się pod koniec drugiej połowy XX wieku i mimo całej jego niejasności jest coraz częściej stosowane do opisu dzisiejszej rodziny. Artykuł ukazuje główne przyczyny dokonujących się przemian, związki między przemianami społeczeństwa i rodziny oraz opisuje modele rodziny: rodzinę tradycyjną (przednowoczesną), nowoczesną i ponowoczesną. Autor koncentruje swoją uwagę na społeczno-kulturowych wskaźnikach rodziny ponowoczesnej. Obserwacja dokonujących się przemian pozwala wyłonić pewne nowe i specyficzne cechy współczesnej rodziny. Może to mieć ważne znaczenie dla zrozumienia rodziny, badań naukowych oraz różnych działań związanych $\mathrm{z}$ jej ulepszaniem. Na pytanie zawarte w tytule trudno jeszcze jednoznacznie odpowiedzieć. Być może potrzebujemy jeszcze więcej czasu, dystansu i wyników badań, aby zauważyć ten fakt. Odpowiedź twierdząca determinowałaby poważne konsekwencje dla polityki rodzinnej, edukacji, terapii rodziny i pracy socjalnej z rodziną.

Słowa kluczowe: rodzina tradycyjna, rodzina nowoczesna, rodzina ponowoczesna, przemiany społeczeństwa, przemiany rodziny w społeczeństwie 
